\title{
Serum Ferritin: Is It an Independent Predictor of Reduced Bone Mineral Density among Elderly Women?
}

\author{
Shereen M. Mousa' ${ }^{1}$, Abeer A. Ibrahim ${ }^{1}$, Rima A. Al Adsani ${ }^{2}$ \\ ${ }^{1}$ Geriatric Department, Faculty of Medicine, Ain Shams University, Cairo, Egypt \\ ${ }^{2}$ Department of Family Medicine, Ahmadi Hospital, Ahmadi, Kuwait \\ Email: *abeerabdelzaher@yahoo.com
}

How to cite this paper: Mousa, S.M., Ibrahim, A.A. and Al Adsani, R.A. (2016) Serum Ferritin: Is It an Independent Predictor of Reduced Bone Mineral Density among Elderly Women? Advances in Aging Research, 5, 142-150.

http://dx.doi.org/10.4236/aar.2016.56014

Received: September 3, 2016

Accepted: October 8, 2016

Published: October 11, 2016

Copyright $\odot 2016$ by authors and Scientific Research Publishing Inc. This work is licensed under the Creative Commons Attribution International License (CC BY 4.0).

http://creativecommons.org/licenses/by/4.0/ (c) (i) Open Access

\begin{abstract}
Aim: In vitro studies have shown that iron promotes osteoclast differentiation and bone-resorbing activity by enhancing mitochondrial biogenesis, whereas it suppresses osteoblastogenesis. In postmenopausal women, serum ferritin increases by 2 3 times due to the lack of a major mechanism of iron excretion, while menstrual blood decreases. Based on this observation, it has been hypothesized that in addition to estrogen deficiency, increased iron as a result of menopause could contribute to bone loss in postmenopausal women. So our aim was to investigate the association between serum ferritin levels and bone mineral density (BMD) in elderly women at various skeletal sites. Methods: Retrospective analysis of the medical records of 71 postmenopausal women having a mean age of (66 \pm 7 ) years (range $60-83$ years) was done. The collected data included age of menopause, past medical history, smoking habits, physical activity, and medication use. BMD was measured at the lumbar spine and femur by dual-energy X-ray absorptiometry, and other biochemical markers including, serum ferritin, 25 hydroxyvitamin D3, serum alkaline phosphatase, and parathyroid hormone were assayed. Results: We found that serum ferritin levels are significantly related to BMD of the total hip and lumbar vertebrae [with a $p$ value of $(0.01)$ and $(<0.001)$ respectively] and $\mathrm{T}$ scores for the total hip, femur neck and lumber vertebrae [with a p value of $(0.004),(0.036)$ and $(<0.001)$ respectively] and their major determinants are age of menopause, menopause duration, weight, BMI and physical activity. Conclusion: This study suggests a positive association between serum ferritin levels and BMD in elderly women without hematologic disorders. Further study is warranted to verify the effects of iron on bone metabolism.
\end{abstract}

\section{Keywords}

Bone Mineral Density, Ferritin, Iron, Osteoporosis, Women 


\section{Introduction}

As women age they lose their bone mass more quickly than men. Estrogen deficiency is the main cause of postmenopausal osteoporosis as it is associated with increased bone turnover rate and remodeling imbalance of bone resorption exceeding bone formation [1]. Additionally, serum ferritin is known to increase by 2 - 3 times during this period due to lack of iron excretion while menstrual blood decreases [2] [3] In vitro studies revealed that iron promotes osteoclast differentiation and bone-resorbing activity [4], and suppresses osteoblastogenesis [5] [6]. Based on this observation, it has been hypothesized that in addition to estrogen deficiency, increased iron as a result of menopause could contribute to bone loss in postmenopausal women [7]. Moreover, ironoverloaded mice have increased oxidative stress and bone resorption which leads to changes in bone microarchitecture and material properties and thus bone loss [8].

Several studies revealed that patients with hemochromatosis, thalassemia and sickle cell anemia have reduced Bone Mineral Density (BMD) compared to the general population [9]-[13]. Such findings support the possible negative effect of iron overload expressed in serum ferritin on BMD and bone metabolism.

However the influence of increased serum ferritin levels and, more generally, the effect of iron on BMD in elderly people without hematologic disorders is uncertain.

Therefore, in the present study we investigated the association between serum ferritin levels and BMD in elderly women at various skeletal sites.

\section{Methods}

A retrospective analysis based on medical records of 71 elderly female patients attending the osteoporosis clinic, Ahmadi Hospital, Kuwait, for osteoporosis screening, from December 2014 to June 2015 was done. The mean age of patients was $(66 \pm 7)$ years (range 60 - 83 years). The collected data included age of menopause, past medical history, personal and parental history of fracture, smoking habits, physical activity, and medication use.

All subjects within the determined period were included in the study except those who have chronic diseases that may affect serum ferritin level after reviewing investigations. Exclusion criteria involved chronic kidney disease, chronic liver disease, neoplastic disease, pulmonary or extrapulmonarytuberculosis, history of recent infection, chronic inflammatory diseases as rheumatoid arthritis or inflammatory bowel disease, anemia or history of hereditary anemia, low serum iron, current thyroid disease or treatment for it, history of osteoporosis or history of treatment for osteoporosis, and hormonal replacement therapy. Finally, subjects with exceptionally high serum ferritin levels (>300 ug/L) were excluded in order to rule out those who could potentially have hemochromatosis. [14]

Life style pattern regarding physical activity levels was addressed. It was estimated with a recall of hours of physical activity per week. It was divided into 3 categories, inactive or sedentary (no significant physical activity), slight activity $(<30 \mathrm{~min} /$ day, less than 3 days/week) and active ( $>30 \mathrm{~min} /$ day more than 3 days/week). 
Anthropometric measures as weight and height were collected and body mass index (BMI) was calculated for each subject.

Plasma concentrations of 25-hydroxycholecalciferol, alkaline phosphatase (ALP), parathyroid hormone $(\mathrm{PTH})$, calcium $\left(\mathrm{Ca}^{2+}\right)$, and iron were collected. Serum ferritin was measured using particle enhanced immunoturbidimetric assay. Human ferritin agglutinates with latex particles coated with anti-ferritin antibodies. The precipitate is determined turbidimetrically at 570/800 $\mathrm{nm}$. BMD $\left(\mathrm{g} / \mathrm{cm}^{2}\right)$ was measured using dualenergy X-ray absorptiometry (DXA; Discovery w (S/N 83889), Hologic, Waltham, MA, USA), it was performed at the lumbar spine (L1-L4), femur neck, and total hip.

\section{Statistical methodology:}

Statistical analyses were performed using SPSS 17.0 (SPSS, Chicago, IL, USA). Inferential analyses were done for quantitative variables using independent $t$ test in cases of two independent groups with parametric data. Inferential analyses were done for qualitative data using Chi-square test for independent variables. For all tests, a two-tailed p-value $<0.05$ was considered statistically significant. Relevant variables with statistical significance in univariate analysis were selected for multivariate logistic regression to identify independent risk factors.

\section{Results}

The characteristics of the studied population are shown in Table 1. Regarding serum ferritin levels, it was observed that they are significantly related to BMD and T scores and their major determinants are age of menopause, menopause duration, weight, and BMI. Serum ferritin was found to be elevated in 8 females of our participants, in whom the lowest BMD for the total hip $(0.6872 \pm 0.12839)$, and lumbar vertebrae $(0.7550 \pm$ $0.04308)$ was detected with a $\mathrm{p}$ value of $(0.01)$ and $(<0.001)$ respectively. They also got the lowest $\mathrm{T}$ score for the total hip $(-1.8500 \pm 0.92273)$, femur neck $(-2.3500 \pm 0.84853)$, and lumbar vertebrae $(-2.6375 \pm 0.40333)$ with a p value of $(0.004),(0.036)$ and $(<0.001)$ respectively. Higher serum ferritin levels were found to be strongly related to the early age of menopause $(p=0.025)$ and long menopausal periods $(p=0.025)$ (Table 2$)$. Physical activity which is another important determinant of BMD was found to be strongly related to lower ferritin levels and the higher the ferritin levels are the less the physical activity of a participant $(\mathrm{p}=0.003)$ (Table 3$)$. Correlating serum ferritin values with different quantitative variables proved that serum ferritin has a significant positive correlation with duration of menopause $(\mathrm{p}=0.019)$ and a negative correlation with age of menopause ( $p=0.006)$ and hip T score $(\mathrm{p}=0.018)$ (Table 4$)$. Finally linear regression model of independent factors affecting BMD and $\mathrm{T}$ score at different measurement sites proved higher serum ferritin to be an independent risk factor for reduced hip and lumbar $\mathrm{T}$ score $(\mathrm{p}=0.002)$ while age and vitamin. $\mathrm{D}$ levels were independent risk to reduced $\mathrm{BMD}$ and $\mathrm{T}$ scores at all measurement sites (Table 5).

\section{Discussion}

Ferritin is the key control of iron amount in the body. It stores and release iron in a 
controlled fashion. It acts as a buffer against iron deficiency and as storage in case of iron excess [15]. Though the fundamental biology of serum ferritin remains unclear, it has growing roles in iron delivery, angiogenesis, inflammation, immunity, signaling and cancer [16].

Serum ferritin also appears to associate aging process. Inflammaging; which is a subclinical inflammatory state that associates aging and thought to be a mechanism of it, is associated with increased levels of serum ferritin [17]. High ferritin levels and excess iron storage exerts its hazards that should be looked for. One of these hazards is reduced BMD. It was found that healthy adults who have elevated serum levels of ferritin have increased rates of bone loss [18].

In a study by Chon and colleagues [19] serum ferritin levels were higher in postmenopausal females compared to premenopausal ones and showed a significant correlation with BMD on lumbar spines. This goes in accordance with our study where our female population who had elevated ferritin levels showed a significant reduction in BMD in both hip and lumbar spines. In contrast Heidari et al. [20] in their study to determine factors affecting BMD in postmenopausal women found that high serum ferritin levels are associated with reduced risk of osteoporosis in lumbar spine and femur

Table 1. Characteristics of the studied population.

\begin{tabular}{|c|c|c|c|c|}
\hline & Minimum & Maximum & Mean & Std. deviation \\
\hline Age & 60.00 & 83.00 & 66.4507 & 7.01588 \\
\hline Menopause & 44.00 & 58.00 & 51.4507 & 3.47969 \\
\hline Weight $(\mathrm{kg})$ & 51.00 & 115.00 & 78.1915 & 12.59978 \\
\hline Height $(\mathrm{cm})$ & 141.00 & 165.00 & 152.7465 & 5.60476 \\
\hline $\mathrm{BMI}^{\dagger}$ & 18.73 & 46.78 & 33.567 & 5.489 \\
\hline${ }^{\star}$ Serum ferritin $(\mathrm{ug} / \mathrm{L})$ & 16.02 & 290.60 & 95.8976 & 69.67446 \\
\hline Hip BMD & 0.01 & 1.21 & 0.8427 & 0.18497 \\
\hline Hip T score & -3.70 & 2.20 & -0.6803 & 1.25375 \\
\hline Femur neck BMD & 0.38 & 1.05 & 0.6827 & 0.13358 \\
\hline Femur neck T score & -4.20 & 1.80 & -1.4911 & 1.23854 \\
\hline Lumbar vertebrae BMD & 0.63 & 1.31 & 0.8790 & 0.15798 \\
\hline Lumbar vertebrae $\mathrm{T}$ score & -3.80 & 2.40 & -1.5048 & 1.46546 \\
\hline *25-hydroxycholecalciferol $(\mathrm{ng} / \mathrm{ml})$ & 4.00 & 64.70 & 20.3177 & 12.26267 \\
\hline${ }^{*} \mathrm{PTH}^{\S}(\mathrm{pmol} / \mathrm{L})$ & 2.98 & 28.70 & 6.2210 & 3.27081 \\
\hline${ }^{\star}$ Serum ALP` $(\mathrm{U} / \mathrm{L})$ & 41.00 & 202.00 & 79.2410 & 24.42734 \\
\hline${ }^{\star}$ Serum iron $($ umol/L) & 1.40 & 27.80 & 13.3792 & 4.63008 \\
\hline${ }^{\star}$ Serum $\mathrm{Ca}^{2+\dagger \dagger}(\mathrm{mmol} / \mathrm{L})$ & 2.08 & 18.89 & 2.5656 & 1.96858 \\
\hline
\end{tabular}

${ }^{\dagger} \mathrm{BMI}=$ Body Mass Index; ${ }^{\mathrm{B}} \mathrm{BMD}=$ Bone Mineral Density; ${ }^{\circledR} \mathrm{PTH}=$ Parathyroid Hormone; ${ }^{\circ} \mathrm{ALP}=$ Alkaline Phosphatase; ${ }^{\dagger \dagger} \mathrm{Ca}^{2+}=$ Calcium. ${ }^{*}$ Reference values: Serum Ferritin (Ref. 15 - $150 \mathrm{ug} / \mathrm{L}$ ), 25-hydroxycholecalciferol (Ref. 30 - 75 ng/ml), PTH (Ref. 0.5 - 6.89 pmol/L), Serum ALP (Ref. 35 - 104 U/L), Serum Iron (Ref. 6 - 26 umol/L), Serum Ca (Ref. 2.2 to $2.55 \mathrm{mmol} / \mathrm{L}$ ). 
Table 2. Relationship between serum ferritin and different studied variables.

\begin{tabular}{|c|c|c|c|c|c|}
\hline & Serum ferritin ${ }^{\star}$ & $\mathrm{N}$ & Mean & Std. deviation & $\mathrm{p}$ \\
\hline \multirow{2}{*}{ Age } & High & 8 & 69.6250 & 8.07001 & 0.18 \\
\hline & Normal & 63 & 66.0476 & 6.83782 & \\
\hline \multirow{2}{*}{ Menopause } & High & 8 & 48.8750 & 3.94380 & 0.025 \\
\hline & Normal & 63 & 51.7778 & 3.30905 & \\
\hline \multirow{2}{*}{ Menopause duration } & High & 8 & 20.7500 & 8.03119 & \multirow{2}{*}{0.025} \\
\hline & Normal & 63 & 14.2698 & 7.49022 & \\
\hline \multirow{2}{*}{ Weight } & High & 8 & 68.2125 & 9.00261 & \multirow[t]{2}{*}{0.02} \\
\hline & Normal & 63 & 79.4587 & 12.47428 & \\
\hline \multirow{2}{*}{ Height } & High & 8 & 152.6250 & 3.99777 & \multirow[t]{2}{*}{0.95} \\
\hline & Normal & 63 & 152.7619 & 5.80174 & \\
\hline \multirow{2}{*}{$\mathrm{BMI}^{\dagger}$} & High & 8 & 29.3775 & 4.67623 & \multirow{2}{*}{0.021} \\
\hline & Normal & 63 & 34.0990 & 5.38476 & \\
\hline \multirow{2}{*}{ Hip BMD $^{\ddagger}$} & High & 8 & 0.6872 & 0.12839 & \multirow[t]{2}{*}{0.01} \\
\hline & Normal & 63 & 0.8624 & 0.18236 & \\
\hline \multirow{2}{*}{ Hip T score } & High & 8 & -1.8500 & 0.92273 & \multirow[t]{2}{*}{0.004} \\
\hline & Normal & 63 & -0.5317 & 1.21640 & \\
\hline \multirow{2}{*}{ Femur Neck BMD } & High & 8 & 0.5981 & 0.10300 & \multirow[t]{2}{*}{0.06} \\
\hline & Normal & 63 & 0.6934 & 0.13382 & \\
\hline \multirow{2}{*}{ Femur Neck T score } & High & 8 & -2.3500 & 0.84853 & \multirow[t]{2}{*}{0.036} \\
\hline & Normal & 63 & -1.3821 & 1.24232 & \\
\hline \multirow{2}{*}{ Lumbar vertebrae BMD } & High & 8 & 0.7550 & 0.04308 & \multirow[t]{2}{*}{0.00} \\
\hline & Normal & 63 & 0.8947 & 0.16042 & \\
\hline \multirow{2}{*}{ Lumbar vertebrae $\mathrm{T}$ score } & High & 8 & -2.6375 & 0.40333 & \multirow[t]{2}{*}{0.000} \\
\hline & Normal & 63 & -1.3610 & 1.48988 & \\
\hline \multirow{2}{*}{ 25-hydroxychole-calciferol } & High & 8 & 15.7125 & 8.62054 & \multirow[t]{2}{*}{0.26} \\
\hline & Normal & 63 & 20.9025 & 12.58180 & \\
\hline \multirow{2}{*}{$\mathrm{PTH}^{\S}$} & High & 8 & 6.1513 & 1.82686 & \multirow[t]{2}{*}{0.95} \\
\hline & Normal & 63 & 6.2298 & 3.42069 & \\
\hline \multirow{2}{*}{ Serum ALP } & High & 8 & 79.1250 & 25.92537 & \multirow[t]{2}{*}{0.99} \\
\hline & Normal & 63 & 79.2557 & 24.44997 & \\
\hline \multirow{2}{*}{ Serum $\mathrm{Ca}^{2+\dagger \dagger}$} & High & 8 & 2.2962 & 0.07836 & \multirow{2}{*}{0.7} \\
\hline & Normal & 63 & 2.5998 & 2.08904 & \\
\hline
\end{tabular}

${ }^{\dagger} \mathrm{BMI}=$ Body Mass Index; ${ }^{\sharp} \mathrm{BMD}=$ Bone Mineral Density; ${ }^{\circledR} \mathrm{PTH}=$ Parathyroid Hormone; ${ }^{\mathrm{A}} \mathrm{ALP}=$ Alkaline Phosphatase; ${ }^{\dagger \dagger} \mathrm{Ca}^{2+}=$ Calcium. ${ }^{*}$ Reference values: Serum Ferritin (Ref. low $<15$, high $>150 \mathrm{ng} / \mathrm{ml}$ ). 
Table 3. Relationship between serum ferritin and physical activity and presence of fractures.

\begin{tabular}{cccccc}
\hline & N & Mean & SD & P \\
\hline \multirow{3}{*}{ Ferritin } & Physical activity & & & & \\
& Inactive & 37 & 121.5954 & 82.37090 & \\
& Slight activity & 30 & 70.6853 & 37.74850 & 0.003 \\
& Active & 4 & 47.2850 & 10.32150 & \\
\hline \multirow{2}{*}{ Ferritin } & Fracture & & & & 0.26 \\
& Yes & 8 & 122.3725 & 98.55729 & \\
\hline
\end{tabular}

${ }^{\dagger} \mathrm{SD}=$ Standard Deviation

Table 4. Correlation between serum ferritin and different studied variables.

\begin{tabular}{|c|c|c|}
\hline variable & $\mathrm{R}$ & $\mathrm{p}$ \\
\hline Age & 0.146 & 0.225 \\
\hline Age of menopause & -0.325 & 0.006 \\
\hline Duration of menopause & 0.277 & 0.019 \\
\hline Weight & -0.212 & 0.076 \\
\hline Height & -0.014 & 0.907 \\
\hline $\mathrm{BMI}^{\dagger}$ & -0.196 & 0.101 \\
\hline Hip BMD & -0.192 & 0.108 \\
\hline Hip T score & -0.281 & 0.018 \\
\hline Femur neck BMD & -0.217 & 0.070 \\
\hline Femur neck $\mathrm{T}$ score & -0.234 & 0.050 \\
\hline Lumbar vertebrae BMD & -0.244 & 0.040 \\
\hline Lumbar vertebrae $\mathrm{T}$ score & -0.227 & 0.057 \\
\hline 25-hydroxychole-calciferol & -0.156 & 0.193 \\
\hline $\mathrm{ALP}^{\S}$ & -0.052 & 0.665 \\
\hline Serum $\mathrm{Ca}^{2+\boldsymbol{g}}$ & -0.133 & 0.268 \\
\hline Serum iron & 0.237 & 0.046 \\
\hline
\end{tabular}

${ }^{\dagger} \mathrm{BMI}=$ Body Mass Index; ${ }^{\ddagger} \mathrm{BMD}=$ Bone Mineral Density; ${ }^{\mathrm{S}} \mathrm{ALP}=$ Alkaline Phosphatase; ${ }^{9} \mathrm{Ca}^{2+}=$ Calcium.

neck. Our selection criteria excluded most of females who has causes for increased serum ferritin levels which resulted in the small sample size and may be responsible for the inability to detect ferritin as an independent variable affecting BMD.

Regarding ferritin levels and other studied variables, we observed that high serum ferritin was significantly related to early menopause and long menopausal duration which is supported by Kim et al. [21] who concluded that from premenopause to postmenopause, women experience an increase in their iron stores. Elevated ferritin levels were observed to be higher in participants with the lowest weight $(68.21 \pm 9)$ and BMI 
Table 5. Linear regression model for independent factors affecting BMD and T score.

\begin{tabular}{|c|c|c|c|c|}
\hline Factor & $\beta^{\dagger}$ & $\mathrm{SE}^{\ddagger}$ & $\mathrm{P}$ & $95 \% \mathrm{CI}^{\S}$ \\
\hline \multicolumn{5}{|c|}{ Hip BMD } \\
\hline Age & 0.011 & 0.001 & $<0.001$ & $0.009-0.012$ \\
\hline 25-hydroxychole-calciferol & 0.006 & 0.002 & $<0.001$ & $0.002-0.010$ \\
\hline \multicolumn{5}{|c|}{ Hip T score } \\
\hline Age & -0.010 & 0.005 & 0.063 & $-0.020-0.001$ \\
\hline 25-hydroxychole-calciferol & 0.021 & 0.011 & 0.072 & $-0.002-0.043$ \\
\hline Serum ferritin & -0.004 & 0.002 & 0.035 & $-0.009-0.000$ \\
\hline \multicolumn{5}{|c|}{ Femur neck BMD } \\
\hline Age & 0.009 & 0.001 & $<0.001$ & $0.008-0.010$ \\
\hline 25-hydroxychole-calciferol & 0.004 & 0.001 & 0.004 & $0.001-0.007$ \\
\hline \multicolumn{5}{|c|}{ Femur neck $\mathrm{T}$ score } \\
\hline Age & -0.029 & 0.004 & $<0.001$ & $-0.037-0.021$ \\
\hline 25-hydroxychole-calciferol & 0.022 & 0.011 & 0.056 & $-0.001-0.044$ \\
\hline \multicolumn{5}{|c|}{ Lumbar BMD } \\
\hline Age & 0.011 & 0.001 & $<0.001$ & $0.010-0.012$ \\
\hline Serum Vit-D & 0.006 & 0.002 & $<0.001$ & $0.003-0.009$ \\
\hline \multicolumn{5}{|c|}{ Lumbar T score } \\
\hline Age & -0.024 & 0.006 & $<0.001$ & $-0.037-0.012$ \\
\hline Serum Vit-D & 0.027 & 0.013 & 0.050 & $0.000-0.053$ \\
\hline Serum ferritin & -0.004 & 0.002 & 0.093 & $-0.009-0.001$ \\
\hline
\end{tabular}

${ }^{\dagger} \beta$ : Regression coefficient; ${ }^{\ddagger} \mathrm{SE}$ : Standard error; ${ }^{\varsigma} \mathrm{CI}$ : Confidence interval; ${ }^{9} \mathrm{BMD}=$ Body Mass Index.

(29.38 \pm 4.68). The relationship between serum ferritin and anthropometric measures was not studied thoroughly, yet it worth mentioning that, the prevalence of obesity in Kuwaiti studies with a nationally representative sample ranged from $24 \%$ to $48 \%$, and in adults $>50$ years was $>52 \%$. Rates were significantly higher in women than those in men [22]. Such facts may bias the relationship between serum ferritin and anthropometric measures in this study.

Higher serum ferritin levels were observed to associate poor physical activity. This agrees with Furqan et al. [23] and Liu et al. [24] who reported that physical activities reduce serum ferritin concentration. Finally serum ferritin was proved by linear regression model to be an independent risk for reduced $\mathrm{T}$ score at both hip and lumbar vertebrae. This relation was not evident for BMD in the regression model. It could be attributed to the small sample size of the studied population. More research is needed to address this relation.

\section{Conclusion}

Serum ferritin plays important roles in different organ function and its related pathology. This study tried to highlight its effect on BMD. Our study suggests a positive asso- 
ciation between serum ferritin levels and BMD in elderly women without hematologic disorders. Further study is warranted to verify the effects of iron on bone metabolism.

\section{References}

[1] Harrison, P.M. and Arosio, P. (1996) The Ferritins: Molecular Properties, Iron Storage Function and Cellular Regulation. Biochimica et Biophysica Acta, 1275, 161-203. http://dx.doi.org/10.1016/0005-2728(96)00022-9

[2] McCance, R.A. and Widdowson, E.M. (1938) The Absorption and Excretion of Iron Following Oral and Intravenous Administration. Journal of Physiology, 94, 148-154. http://dx.doi.org/10.1113/jphysiol.1938.sp003669

[3] Milman, N. and Kirchhoff, M. (1992) Iron Stores in 1359, 30- to 60-Year-Old Danish Women: Evaluation by Serum Ferritin and Hemoglobin. Annals of Hematology, 63, 103135. http://dx.doi.org/10.1007/bf01811467

[4] Ishii, K.A., Fumoto, T., Iwai, K., et al. (2009) Coordination of PGC1beta and Iron Uptake in Mitochondrial Biogenesis and Osteoclast Activation. Nature Medicine, 15, 259-266. http://dx.doi.org/10.1038/nm.1910

[5] Yamasaki, K. and Hagiwara, H. (2009) Excess Iron Inhibits Osteoblast Metabolism. Toxicology Letters, 191, 211-215. http://dx.doi.org/10.1016/j.toxlet.2009.08.023

[6] Yang, Q., Jian, J., Abramson, S.B. and Huang, X. (2011) Inhibitory Effects of Iron on Bone Morphogenetic Protein 2-Induced Osteoblastogenesis. Journal of Bone and Mineral Research, 26, 1188-1196. http://dx.doi.org/10.1002/jbmr.337

[7] Jian, J., Pelle, E. and Huang, X. (2009) Iron and Menopause: Does Increased Iron Affect the Health of Postmenopausal Women? Antioxidants \& Redox Signaling, 11, 2939-2943. http://dx.doi.org/10.1089/ars.2009.2576

[8] Tsay, J., Yang, Z., Ross, F.P., et al. (2010) Bone Loss Caused by Iron Overload in a Murine Model: Importance of Oxidative Stress. Blood, 116, 2582-2589. http://dx.doi.org/10.1182/blood-2009-12-260083

[9] Valenti, L., Varenna, M., Fracanzani, A.L., Rossi, V., Fargion, S. and Sinigaglia, L. (2009) Association between Iron Overload and Osteoporosis in Patients with Hereditary Hemochromatosis. Osteoporosis International, 20, 549-555.

http://dx.doi.org/10.1007/s00198-008-0701-4

[10] Mahachoklertwattana, P., Sirikulchayanonta, V., Chuansumrit, A., et al (2003) Bone Histomorphometry in Children and Adolescents with Beta-Thalassemia Disease: Iron-Associated Focal Osteomalacia. Journal of Clinical Endocrinology and Metabolism, 88, 39663972. http://dx.doi.org/10.1210/jc.2002-021548

[11] Voskaridou, E. and Terpos, E. (2004) New Insights into the Pathophysiology and Management of Osteoporosis in Patients with Beta-Thalassaemia. British Journal of Haematology, 127, 127-139. http://dx.doi.org/10.1111/j.1365-2141.2004.05143.x

[12] Salama, O.S., Al-Tonbary, Y.A., Shahin, R.A. and Eldeen, O.A. (2006) Unbalanced Bone Turnover in Children with Beta-Thalassemia. Hematology, 11, 197-202. http://dx.doi.org/10.1080/10245330600702851

[13] Sarrai, M., Duroseau, H., D’Augustine, J., Moktan, S. and Bellevue, R. (2007) Bone Mass Density in Adults with Sickle Cell Disease. British Journal of Haematology, 136, 666-672. http://dx.doi.org/10.1111/j.1365-2141.2006.06487.x

[14] Brandhagen, D.J., Fairbanks, V.F. and Baldus, W. (2002) Recognition and Management of Hereditary Hemochromatosis. American Family Physician, 65, 853-860. 
[15] Casiday, R. and Frey, R. (2000) Iron Use and Storage in the Body: Ferritin and Molecular Representations Iron in Biology: Study of the Iron Content in Ferritin. The Iron-Storage Protein, Washington University.

http://www.chemistry.wustl.edu/ edudev/LabTutorials/Ferritin/Ferritin.html

[16] Wang, W., Knovich, M.A., Coffman, L.G., Torti, F.M. and Torti, S.V. (2010) Serum Ferritin: Past, Present and Future. Biochimica et Biophysica Acta (BBA)-General Subjects, 1800, 760-769. http://dx.doi.org/10.1016/j.bbagen.2010.03.011

[17] Cankurtaran, M., Yavuz, B.B., Halil, M., Ulger, Z., Haznedaroğlu, I.C. and Arığul, S. (2012) Increased Ferritin Levels Could Reflect Ongoing Aging-Associated Inflammation and May Obscure Underlying Iron Deficiency in the Geriatric Population. European Geriatric Medicine, 3, 277-280. http://dx.doi.org/10.1016/j.eurger.2012.06.005

[18] Mitchell, F. (2012) Bone: High Body Iron Stores Lead to Bone Loss. Nature Reviews Endocrinology, 8, 506. http://dx.doi.org/10.1038/nrendo.2012.127

[19] Chon, S.J., Choi, Y.R., Roh, Y.H., et al. (2014) Association between Levels of Serum Ferritin and Bone Mineral Density in Korean Premenopausal and Postmenopausal Women: KNHANES 2008-2010. PLOS ONE, 9, e114972. http://dx.doi.org/10.1371/journal.pone.0114972

[20] Heidari, B., Hosseini, R., Javadian, Y., Bijani, A., Sateri, M.H. and Nouroddini, H.G. (2015) Factors Affecting Bone Mineral Density in Postmenopausal Women. Archives of Osteoporosis, 10, 15. http://dx.doi.org/10.1007/s11657-015-0217-4

[21] Kim, C., Nan, B., Kong, S. and Harlow, S. (2012) Changes in Iron Measures over Menopause and Associations with Insulin Resistance. Journal of Women's Health, 21, 872-877. http://dx.doi.org/10.1089/jwh.2012.3549

[22] Karageorgi, S., Alsmadi, O. and Behbehani, K. (2013) A Review of Adult Obesity Prevalence, Trends, Risk Factors, and Epidemiologic Methods in Kuwait. Journal of Obesity, 2013, Article ID: 378650.

[23] Furqan, M., Nafees, M., Jilani, T. and Hijazi, M. (2002) Relationship between Physical Activity and Serum Ferritin Levels. PakMediNet, 7, 306-309.

[24] Liu, J.M., Hankinson, S.E., Stampfer, M.J., Rifai, N., Will, W.C. and Ma, J. (2003) Body Iron Stores and Their Determinants in Healthy Postmenopausal US Women. The American Journal of Clinical Nutrition, 78, 1160-1167.

\section{Submit or recommend next manuscript to SCIRP and we will provide best service for you:}

Accepting pre-submission inquiries through Email, Facebook, LinkedIn, Twitter, etc.

A wide selection of journals (inclusive of 9 subjects, more than 200 journals)

Providing 24-hour high-quality service

User-friendly online submission system

Fair and swift peer-review system

Efficient typesetting and proofreading procedure

Display of the result of downloads and visits, as well as the number of cited articles

Maximum dissemination of your research work

Submit your manuscript at: http://papersubmission.scirp.org/

Or contact aar@scirp.org 